\title{
Een religieuze vrije val in Venray
}

\section{Het verdwijnen van kloosterlingen tussen 1965 en 2005}

Frans Jespers Q Riky de Jong*

\section{Summary}

In Venray, a country town in the south of the Netherlands, several hundreds of Roman Catholic religious lived and worked around the middle of the twentieth century. Eight different orders and congregations had their monasteries and convents for priests, brothers and sisters. Their main tasks concerned education (especially in boarding schools), nursing and psychiatric care. Between 1965 and 2005 more than 400 of them left, mainly because their tasks were taken over by lay people, which was a consequence of the development of the welfare state. In the seventies and eighties many other cultural changes led to big tensions within the monasteries and convents. Although the religious made various attempts to renew their rules and life, they were not able to stop the ongoing decrease of their numbers. The short history of those eight religious communities in Venray and their social practices is a good example of the recent history of active Roman Catholic religious in the Netherlands. Probably, in Venray their decline even went a bit faster than in most other Dutch places. Most of the 'superfluous' priests, brothers and nuns went to larger cities in order to develop alternative social activities, for which was no opportunity in a country town like Venray.

\section{Bloei en verval van het kloosterleven in Venray}

Op religieus gebied lijkt Venray nauwelijks af te wijken van de rest van Nederland. De rijzige toren van de Sint-Petrus' Bandenkerk domineert wel het centrum van deze provinciestad in Noord-Limburg, maar de kerk is meestal gesloten. In het dagelijks leven van de meeste inwoners speelt godsdienst geen rol van betekenis meer. Slechts een paar gebouwen in het centrum verwijzen nog naar een levendig religieus verleden dat in de afgelopen halve eeuw op spectaculaire wijze is verdampt. Want in Venray zijn binnen vier

\footnotetext{
* Frans Jespers was tot voor kort universitair hoofddocent vergelijkende godsdienstwetenschap aan de Radboud Universiteit Nijmegen.

Riky de Jong studeerde na een loopbaan in het maatschappelijk werk religiestudies.
} 
decennia honderden kloosterlingen vertrokken, schijnbaar in hoger tempo dan in enige andere Nederlandse stad. Dit gegeven lijkt Venray tot een unieke casus te maken. Hoe kon hier in een periode van veertig jaar, tussen 1965 en 2005, een soort religieuze vrije val plaatsvinden?

Het hoogste aantal kloosterlingen in Venray moet omstreeks 1940 bereikt zijn (Bak et al. 1998, 27, 38, 79). Op een totale bevolking van ongeveer 8000 inwoners waren er toen ruim 600 religieuzen, dus goed zeven procent van de bevolking. In het straatbeeld moeten die kloosterlingen behoorlijk opgevallen zijn, want zij waren allen gekleed in verschillende typen bruin, zwart of wit habijt en de zusters droegen daarbij opvallende kappen. Bovendien waren de kloosters toen de grootste werkgevers, dus de religieuzen hadden ook flinke economische invloed. Om twee redenen zijn er geen exacte getallen in verband met dat hoogtepunt beschikbaar: vanwege de Tweede Wereldoorlog is de bevolkingsadministratie in het ongerede geraakt en in Venray verbleven ook nog eens enkele duizenden psychiatrische patiënten in instellingen. In 1944 lag Venray lange tijd in de frontlinie en raakte het zo zwaar beschadigd, dat talloze inwoners, patiënten en kloosterlingen moesten vertrekken, tijdelijk of voorgoed.

Na de oorlog is Venray weer langzaam opgebouwd. Het aantal kloosterlingen stabiliseerde rond de 450. Maar in het midden van de jaren zestig begon het grote verloop. Veertig jaar later woonden er nog maar 14 religieuzen. Als zij de landelijke trend van de terugloop van kloosterlingen hadden gevolgd, hadden er in 2005 toch nog omstreeks honderd over moeten zijn (Schepens et al. 2002, 54). Waarom liep hun aantal hier zo snel terug? Werd Venray een slecht leef- of werkgebied voor hen, en zo ja, om welke reden dan? Woonden hier specifieke groepen religieuzen die gevoeliger waren voor de secularisatie dan andere groepen? Hierbij kunnen we denken aan het verschil tussen contemplatieve en actieve religieuzen en aan de aard van hun uiteenlopende werkterreinen zoals onderwijs, zorg, sociale inzet of pastoraat.

Voor de terugloop van katholieke religieuzen in Nederland zijn al verschillende verklaringen gegeven, van een natuurlijke reductie vanwege culturele overbodigheid (Goddijn et al. 1999) tot een proces van uitsterving als gevolg van kerkelijke liberaliseringen (Sengers 2003). Studies over afzonderlijke ordes of congregaties in Nederland tonen aan dat er per groepering vaak verschillende factoren versnellend of vertragend werkten bij de terugloop (Van Vugt 2015). Over de Venrayse kloosters is in 1998 een fraai gedenkboek verschenen, Twaalf stenen uit de stroom: De twaalf kloosters van Venray, dat vooral documentair van aard is (Bak et al. 1998). Hierin treffen we geen 
overzichtelijke cijfers of een verklaring voor de ongewoon snelle verdwijning van de religieuzen aan, eerder een weemoedige terugblik.

Met behulp van literatuurstudie en van sociaal-historische bronnen zullen wij de casus van de snelle terugloop van de kloosterlingen in Venray in kaart brengen. Om te beginnen presenteren we de hoofdlijnen van de geschiedenis van de kloosterlingen in Nederland in de afgelopen halve eeuw en de verklaringen voor hun teruggelopen aantal. Daarna bespreken we de ontwikkelingen van de Venrayse takken van de acht ordes en congregaties die hier actief waren, waarbij in eerste instantie naar de interne geschiedenis gekeken wordt en vervolgens naar de relaties tot de sociale omgeving. Vervolgens worden de belangrijkste gegevens uit de Venrayse kloostergeschiedenis vergeleken met de bredere Nederlandse situatie. Tot slot zoeken we naar specifieke oorzaken van de religieuze vrije val in Venray en bespreken we enige bijkomende verklaringen.

\section{Kloosterlingen in Nederland in de afgelopen halve eeuw}

\section{Hoofdlijnen van de kloostergeschiedenis}

Ondanks de enorme reeks publicaties over groeperingen van kloosterlingen in Nederland in de twintigste eeuw zijn er nog weinig overzichtsstudies verschenen; eigenlijk is er alleen een indrukwekkende monografie beschikbaar over de actieve vrouwelijke religieuzen (Van Heijst, Derks \& Monteiro 2010; Van Vugt 2015). Dit is niet verwonderlijk als we bedenken dat het om een kleine 100.000 personen gaat, verdeeld over ruim 150 ordes en congregaties, over honderden kloosters en huizen, en talloze aangelegenheden in binnenen buitenland.

Binnen Nederland zetten de religieuzen zich hoofdzakelijk in voor onderwijs, zieken- en ouderenzorg, maatschappelijk werk, en ondersteuning in de parochiële zielzorg. Hiernaast was er een kleine groep contemplatieve ordes, met een besloten gebedsleven en enige werkzaamheden voor het levensonderhoud (Goddijn et al. 1999, 106). Deze religieuzen hadden zich vooral in de negentiende eeuw vanuit hun eerste vestiging of moederhuis verspreid in netwerken van middelgrote en kleine kloosters waarmee de katholieke bevolking van alle steden en dorpen zoveel mogelijk bediend werd. Bovendien ontstond er in vijf steden een concentratie aan kloosters, waaronder meerdere moederhuizen: Maastricht, Eindhoven, 's-Hertogenbosch, Tilburg en Nijmegen. Men zou ze religieuze kernplaatsen kunnen noemen. 
In de eerste helft van de twintigste eeuw behoorden de kloosterlingen tot de gangmakers van de katholieke emancipatie. De diversiteit van bovengenoemde taken en levensstijlen bood voor ondernemende jongeren van allerlei afkomst en capaciteit wel een haalbaar en hooggewaardeerd ideaal. Het kloosterleven had een hogere religieuze status dan dat van gewone gelovigen. In termen van de rationele-keuzetheorie werden de zware inspanningen van levenslange onbetaalde inzet en dagelijkse gebedsverplichtingen alleen in de verte beloond met eeuwig zielenhiel, maar vooral in dit leven gecompenseerd door sociaal aanzien en carrièremogelijkheden (Sengers 2003, 37-40).

De religieuzen konden, na een opleiding vol vroomheid en discipline, door hun oversten met vrijwel absoluut gezag worden ingezet voor diverse kerkelijke en sociale projecten. Vooral zusters en broeders met verpleegtaken (in ziekenhuizen en gesloten instellingen) hadden vaak zware dagtaken. Zij woonden in de instelling, waardoor een "grenzeloze opoffering" van hen gevergd kon worden (Van Heijst, Derks \& Monteiro 2010, 317). Op grond van het heersende standsbesef en de verzuilingsgedachte konden de religieuzen meestal redelijk overweg met de krachtige hiërarchie binnen en tussen de ordes en congregaties (Ackermans 1999, 61). De strenge discipline werd al in de vooropleiding aangeleerd: zes jaar kleinseminarie voor aankomende paters, enkele jaren juvenaat voor broeders, respectievelijk postulaat voor zusters. Het officiële kennismakingsjaar of noviciaat trok in de eerste helft van de eeuw steeds meer belangstellenden. Het hoogste aantal intredingen lag in feite rond 1935 (Sengers 2003, 9-12; Bosgraaf 2009, 73; Baan 1965, 100). Tegelijk ontstond toen de eerste maatschappelijke kritiek op het religieuze leven en rees er twijfel over de morele superioriteit van kloosterlingen (Van Heijst, Derks \& Monteiro 2010, 723, 733). Kortom, de eisen bleven dezelfde, maar de voordelen begonnen af te brokkelen.

De Tweede Wereldoorlog betekende een breuk in het leven van de Nederlandse kloosters, omdat de bezetting de aanname van nieuwelingen bijna onmogelijk maakte. Veel kloostergebouwen werden gevorderd door het Duitse leger en sommige religieuzen werden vervolgd of moesten onderduiken. Na de oorlog nam men de draad weer op en leken de jongeren als vanouds toe te stromen.

Maar in de jaren vijftig boette het kloosterleven in aan overtuigingskracht. Op de eerste plaats was de katholieke emancipatie min of meer voltooid. Ook religieuzen waren zozeer in de samenleving geaccepteerd, dat hun levensideaal weinig uitdaging meer vertoonde en geen unieke stijgingskans op de maatschappelijke ladder meer bood. Op de tweede plaats ging de schaarstemaatschappij, waarin religieuze zelfopoffering aanzien had gebracht, plaats 
maken voor een welvaartssamenleving, waarbij het religieuze ideaal nauwelijks meer paste. In de verzorgingsstaat nam de overheid de verantwoordelijkheid voor ziekenzorg, sociale zorg en onderwijs geleidelijk over, zodat kloosterlingen hiervoor overbodig werden (Goddijn et al. 1999, 107; Bosgraaf 2009, 74; Van Heijst, Derks \& Monteiro 2010, 437 en 732).

De jaren zestig brachten nog grotere culturele veranderingen (zie volgende paragraaf), waardoor zich steeds minder jongeren meldden voor de opleidingen van de religieuzen, zodat in 1968 de intrede van nieuwelingen vrijwel ophield. In de religieuze onderwijs- en verplegingsinstellingen werden steeds meer gediplomeerde leken in dienst genomen, terwijl (ongediplomeerde) religieuzen werden geweerd of een vrijwilligerstaak kregen. De religieuzen die hun baan behielden, kregen voor het eerst normale arbeidsvoorwaarden, zoals een pensioenleeftijd (Goddijn et al. 1999, 106; Van Heijst, Derks \& Monteiro 2010, 305, 335, 353, 369). Tijdens het Tweede Vaticaans Concilie (1963-1965) zette de kerkelijke leiding de deuren naar de wereld een beetje open, maar de vernieuwing van de kloostertucht werd aan de ordes en congregaties overgelaten, binnen tamelijk traditionele kaders (Goddijn et al. 1999, 106-107). Door al deze ontwikkelingen namen de spanningen binnen en rond de kloostergemeenschappen op veel plaatsen toe.

Eind jaren zestig begon dan ook een periode van tien jaar met veel uittredingen. Honderden paters en broeders namen afscheid van het klooster om te kunnen trouwen, zusters deden dit in mindere mate. Deze grote uitstroom ging echter na 1975 weer geleidelijk over in geringe uittreding. Vanaf deze tijd nam het aantal religieuzen af door overlijden, terwijl de bescheiden aanwas ongeveer gelijke tred hield met de uittredingen (Schepens et al. 2002, 41 en 56; Van Dam 2006, 109-110; Van Heijst, Derks \& Monteiro 2010, 743). Contemplatieve kloosters leken aanvankelijk minder getroffen te worden door deze malaise, maar met enige vertraging daalden daar de aantallen eveneens. Ook de jaren zeventig en tachtig waren een turbulente periode waarin allerlei pogingen werden gedaan om het kloosterleven bij de tijd te brengen. In deze jaren verlieten tevens grote aantallen gewone gelovigen de kerk voorgoed, wat tamelijk ontmoedigend was voor de religieuzen.

Zodoende kan 1967 met 44.165 zusters, broeders, paters en fraters min of meer als kwantitatief hoogtepunt gelden - inclusief de duizenden toen naar de missie en om andere redenen naar het buitenland uitgezonden Nederlandse religieuzen. Vanaf die tijd nam hun aantal met gemiddeld 800 per jaar af tot 9560 in 2005 (www.ru.nl/kaski/onderzoek/cijfers-rooms; Schepens et al. 2002, 54; www.knr.nl/organisatie/leden/cijfers). Toen hadden de meeste over- 
geblevenen zich verzoend met de gedachte dat er voor actieve religieuzen in Nederland weinig toekomst meer was.

\section{Aanpassingen aan culturele veranderingen}

De omslag in de jaren zestig hield zeker verband met de culturele veranderingen in de samenleving. Toch hebben de religieuzen zich ingespannen om met dergelijke ontwikkelingen mee te gaan. Op eerdere aspecten van de modernisering zoals industrialisatie, urbanisatie en algemeen onderwijs hadden kerk en kloosterordes tamelijk adequaat weten te reageren. Zo werkten bijvoorbeeld de religieuzen in het onderwijs en de verpleging hard aan hun professionalisering; velen van hen behaalden officiële diploma's (Van Heijst, Derks \& Monteiro 2010, 121, 183, 367-369).

In de jaren vijftig waren verschillende religieuze oversten al bezorgd over de kloof tussen klooster en wereld, die nu niet langer als bescherming, maar als bedreiging werd opgevat: kloosterlingen wisten onvoldoende wat er in de wereld en onder gewone mensen leefde. Men erkende nu ook nadelen van het religieuze leven: het vergde veel opoffering en was nogal onpersoonlijk en gevoelsarm (Van Heijst, Derks \& Monteiro 2010, 734). Er kwam een interne discussie op gang over de zin van een aantal strenge regels. Er groeide niet alleen twijfel over de gangbare consequenties van de intrede - het 'verzaken van de wereld' - zoals het dragen van een habijt, het verruilen van de eigen naam voor een kloosternaam, of de beperking van sociale contacten (Nissen 1997, 10-12). Nog sterker aarzelde men over zware gebedsverplichtingen (uren per dag en 's nachts), geregeld vasten, soms (opgelegde) zelfkastijding, en vooral vernederende gehoorzaamheidsoefeningen (Bosgraaf 2009, 52-53, 79, 111). Eind jaren vijftig zijn deze regels al afgezwakt. Verder werd in 1957 de Samenwerking Nederlandse Vrouwelijke Religieuzen opgericht om vernieuwing en verdieping te bevorderen bij de actieve religieuzen, onder andere door scholing (Van Heijst, Derks \& Monteiro 2010, 578-583).

In de jaren zestig dienden zich in de hele samenleving een verdere individualisering, toenemend egalitarisme, liberalisering van de omgangsvormen en een voortschrijdende secularisatie aan. Het leven werd positiever opgevat. Daardoor kwam het kloosterleven haaks op de levensstijl van de welvaartssamenleving te staan (Van Heijst, Derks \& Monteiro 2010, 187). Zo oefenden grote, uniforme gemeenschappen minder aantrekkingskracht uit, want mensen zochten een individueel levenspad. Het egalitarisme en het antiautoritaire verzet rond 1968 deden de behoefte aan internaten (voor de kinderen van de elite) verdwijnen, ze maakten de rol van de kerkelijke hiërarchie verdacht en die van leken in de kerk belangrijker. Op de vrouwenemancipatie, door onder 
andere grotere arbeidsparticipatie en de beschikbaarheid van voorbehoedsmiddelen, wist de kerk slechts conservatief te reageren. Voor de liberalisering van (seksuele) omgangsvormen had zij evenmin een oplossing.

Eind jaren zestig spitste de discussie over het kloosterleven zich toe op de eenzijdigheid van de celibaatsverplichting. Tot die tijd waren kloosterlingen opgevoed met een strenge seksuele moraal en een verheerlijking van de ongehuwde staat als een vorm van heiliging door onthechting. Als een weerklank van de nieuwe culturele ideeën over vrije seks en openlijke homoseksualiteit groeide ook onder religieuzen twijfel over het celibaat. Eind jaren zestig deelden zij in de algemene verwachting dat de kerkelijke verplichting weldra opgeheven zou worden (Deetman e.a. 2011, deel 1, 42). Velen vonden het niet langer gezond dat kloosterlingen hun affectiviteit totaal op moesten geven en meenden dat ten minste een relatie-zonder-seks met een persoon van het andere geslacht toegelaten kon worden (Goddijn et al. 1999, 234, 236). Kloosterlingen met seksuele problemen konden vanaf 1967 terecht bij het Caper, het Centraal Adviesbureau voor Priesters en Religieuzen, voor psychologische begeleiding (Deetman et al. 2011, deel 1, 70). In de jaren zeventig kozen velen voor een andere oplossing: uittreden en trouwen. Na 2000 werd bovendien duidelijk dat in de jaren vijftig en zestig de druk van het celibaat nogal wat religieuzen ertoe had gebracht om in hun seksuele behoeften te voorzien door kinderen op hun internaten te misbruiken (Deetman et al. 2011). In instellingen van vrouwelijke religieuzen was dit misbruik aanmerkelijk minder dan bij de mannen (Van Heijst, Derks \& Monteiro 2010, 1034).

In 1968 begonnen de vernieuwingskapittels van de ordes en congregaties en werd een eerste fase van "humanisering van het kloosterleven" merkbaar (Van Heijst, Derks \& Monteiro 2010, 928; Ackermans 1999, 69). Het meest zichtbare effect bij de niet-contemplatieve religieuzen was de opheffing in 1969 van de verplichting om het habijt te dragen. Spoedig waren kloosterlingen in het openbaar niet meer onmiddellijk herkenbaar. In eerste instantie zochten de religieuzen al vanaf het midden van de jaren zestig vernieuwing door te gaan wonen in kleine groepjes ('communiteiten') in woonwijken. Hierdoor konden zij zich in de wereld bewegen, onder gewone mensen, en tevens dagelijks leven en werk beter scheiden (Goddijn et al. 1999, 234-235; De Kok 2007, 504-509). Maar binnen de religieuze gemeenschappen namen de spanningen vaak toe, tussen de meestal behoudende ouderen en de progressieve minderheid van jongeren, tussen opofferingsgezinde idealisten en leden die meer privésfeer of persoonlijke ontplooiing wensten (Van Heijst, Derks \& Monteiro 2010, 794). 
In tweede instantie vonden veel jongere kloosterlingen elkaar, vanaf het midden van de jaren zeventig, in hun sympathie voor de opgekomen maatschappijkritiek. Vooral in de nieuwe Zuid-Amerikaanse bevrijdingstheologie vonden zij inspiratie voor een "radicale optie voor de armen”. Zij stortten zich in projecten van verslaafdenzorg tot politieke protesten. Dergelijke activiteiten kwamen in 1985 samen in de Acht Mei Beweging, een progressieve stroming die "het andere gezicht" van de katholieke kerk wilde tonen en waarmee heel wat religieuzen sympathiseerden. Maar hun sociale engagement botste vaak met de gematigde of behoudende opvattingen van de oudere medebroeders en -zusters, en al helemaal met die van de kerkelijke leiding, waarvan de conservatieve bisschop van Roermond, Joannes Gijsen (1972-1993) een exponent was (Goddijn et al. 1999, 347-349).

In derde instantie, vanaf ongeveer 1985, ontstond de zoektocht naar de oorspronkelijke spiritualiteit van de verschillende ordes en congregaties (De Kok 2007, 556, 573-576). De aandacht voor individuele vroomheid nam weer toe (Ackermans 1999, 71). Bij het concilie was hier al op aangedrongen, maar nu scheen de tijd er pas rijp voor. Vele kloosters werden oorden van bezinning en spirituele oefeningen, waarbij men soms dankbaar teruggreep op traditionele vormen van liturgie. In de jaren tussen 1995 en 2005 kreeg deze kloosterspiritualiteit ook nog de wind mee van de populariteit van holistische spiritualiteit, waardoor zelfs enige wederzijdse beïnvloeding ontstond (De Groot, Pieper \& Putman 2013). Maar in dezelfde periode vanaf 1985 werden de interne tegenstellingen tussen progressieve en conservatieve religieuzen versterkt door de groeiende polarisatie in heel katholiek Nederland, hetgeen verlammend werkte op de samenwerking tussen en uitstraling van de kloosterlingen (Goddijn et al. 1999, 459).

Alles bijeen zijn er dus sinds 1965 en zelfs al in het voorafgaande decennium allerlei pogingen gedaan om het kloosterleven nieuwe impulsen te geven. Maar ze konden het tij niet keren. De hierboven samengevatte analyses van Gian Ackermans, Emke Bosgraaf en Peter Nissen leiden tot de verklaring dat de bewuste vernieuwingen in de kloostertucht onvoldoende en te laat waren, zodat het religieuze leven te zwaar en onaantrekkelijke bleef voor jongeren. De implicatie van het betoog van Erik Sengers is daarentegen, dat de verlichting van de tucht juist de indruk van verslapping maakte, waardoor de uitdaging van het kloosterleven verloren ging (Sengers 2003, 184). Verderop zullen we deze tegengestelde verklaringen afwegen, maar eerst gaan we in op de lokale verhoudingen in Venray. 


\section{De Venrayse kloosters en hun bewoners tussen I965 en 2005}

De ontwikkelingen in de kloosters van de acht ordes en congregaties worden hieronder geschetst in de chronologische volgorde van hun vestiging in Venray. De belangrijkste gebeurtenissen van de afgelopen halve eeuw worden belicht op basis van publicaties over de verschillende groeperingen, aangevuld met enige persoonlijke informatie van betrokken religieuzen. De meeste aandacht gaat uit naar de grootste groepen, waarover ook het meeste is gepubliceerd. Wij hebben ervan afgezien om zelf de huisarchieven van deze kloosters te raadplegen, omdat deze in een aantal publicaties al benut zijn, maar bovendien omdat ze verspreid en ten dele niet openbaar toegankelijk zijn.

\section{De jongste geschiedenis van de acht ordes en congregaties in Venray}

Enige leden van de orde der Minderbroeders Franciscanen hadden vanuit Weert in 1647 in Venray een klooster gesticht. Het bleef twee eeuwen lang een klein convent dat de Franse Tijd en de decennia erna ternauwernood doorstond. Maar na 1850 begon een gestage groei. In het klooster werd de filosofieopleiding van aankomende priester-franciscanen ('fraters') ondergebracht; aan de overzijde van de straat bloeide een kleinseminarie, met het eerste gymnasium met rijkserkenning van Nederland. Op zijn kwantitatieve hoogtepunt, de periode vlak voor de ontruiming door het Duitse leger in 1943, waren hier ruim 200 paters, broeders en fraters gevestigd (Bak et al. 1998, 27, 38). De franciscanen hadden ook de geestelijke zorg voor de meeste zuster- en broederkloosters, en voor de psychiatrische instellingen in Venray, bij elkaar gemiddeld zes rectorfuncties.

In de jaren vijftig rommelde het al op het kleinseminarie, omdat veel studenten die geen priester wilden worden het niet zo nauw namen met de religieuze regels. In 1961 rapporteerde de rector dat de sfeer tussen de paters beroerd was. In 1967 werd het seminarie omgezet in een algemeen jongensinternaat. Een halve eeuw later bleek dat verschillende paters seksueel misbruik hadden gemaakt van pupillen van het seminarie en het internaat. Het tamelijk gedetailleerde rapport-Deetman rept van 54 gevallen van misbruik, maar dit betreft voornamelijk de jaren 1950-1964, dus juist voorafgaand aan de periode die wij onderzoeken. Het rapport gaat dan ook uitvoerig in op de toenmalige leefomstandigheden en het beleid van de orde in verband met misbruik (Deetman et al. 2011, deel 1, 586-587, 686-699).

In 1965 werkten en studeerden er in totaal nog ruim 80 franciscanen in Venray. In de voorafgaande jaren waren bij hen enkele strenge regels afgeschaft, zoals de kruinschering, het nachtkoor en de dagelijkse hoogmis, de 
openbare schuldbelijdenis, de onverwarmde kamers, en een specifieke vorm van versterving: een ochtend per week niet roken. De regel van een meerdaags bezoek aan de eigen familie eenmaal per vier jaar was versoepeld tot eenmaal per jaar. Een enkeling begon zelfs een paar dagen vakantie te nemen (Baan 1965, 290-291). Pater Melchior Baan constateerde al in 1965 dat de individualisering (in de vorm van persoonlijke meningen en praktijken) onder franciscanen toenam, wat tot spanningen leidde en het gemeenschapsleven ontwrichtte (ibidem, 471-474). In diezelfde jaren kwam er kritiek op verschillende paters die als rector in zusterkloosters dienden, omdat ze niet geschikt bleken voor deze zielzorgtaak (Van Heijst, Derks \& Monteiro 2010, 594-597).

In 1967 werd de filosofieopleiding vanwege concentratie verplaatst naar Utrecht, wat het vertrek van ruim de helft van de franciscanen betekende. In ditzelfde jaar werd de 'termijn' afgeschaft, het huis aan huis bedelen bij gelovigen om voedsel en geld (Bak et al. 1998, 32; De Kok 2007). Het internaat werd in 1977 gesloten wegens gebrek aan belangstelling. Het gymnasium was inmiddels omgezet in een scholengemeenschap die nog steeds bestaat, nu onder de naam Raayland College. Vanaf 1967 begonnen de franciscanen zich geleidelijk terug te trekken uit het onderwijs en uit Venray wanneer zij met pensioen gingen. In 1993 vertrok de laatste franciscaanse leraar (Bak et al. $1998,40)$.

Het omvangrijke klooster is in 1970 verkocht en door de nieuwe eigenaar ingericht als verpleeghuis. De 'paterskerk' werd parochiekerk, O.L. Vrouw van Zeven Smarten. Een kleine groep paters bleef tussen 1970 en 1990 actief in de zielzorg bij deze kerk. Ze stichtten in 1976 in de nabijgelegen buitenwijk, 't Brukske, zelfs een nieuwe parochie en een kerk, de Zonneliedkerk, met een kleine communiteit erbij. Toen de pater-pastoor zeven jaar later met emeritaat ging, droeg hij de parochie aan het bisdom over. Bovendien ondersteunden de franciscanen de oecumenische basisgroep Heel de kerk, heel de wereld, die was opgericht in 1984 en nog steeds bestaat (Adriaansens et al., 2004; Bak et al. 1998, 32; www.basisgroepvenray.nl). De Venrayse pater Frans Meijer schreef in 2001 een boekje over Jezus als wijsheidsleraar (Jehosjoea van Natsrat), om dergelijke basisgroepen te inspireren (Meijer 2001). Hij is de laatste pater die een officiële functie vervulde. Na zijn pensionering in 2003 bleef hij in het voormalige klooster, nu verpleeghuis, wonen en werken als priester-voorganger. Tien jaar later vertrok hij als laatste franciscaan naar een klooster elders in het land.

De Zusters Ursulinen van de Romeinse Unie vormen een specifieke onderwijsorde. In 1838 betrokken enige Belgische zusters een vervallen kloostercomplex in Venray, Jeruzalem, van waaruit zij niet alleen de dorpsmeisjes 
onderwijs gaven, maar ook een al spoedig gerenommeerd internaat opzetten voor meisjes van de katholieke elite. Dit werd zo'n doorslaand succes, dat zij vanuit Venray verschillende andere kloosters en scholen konden stichten. De zusters die het onderwijs verzorgden waren hoog gekwalificeerd. Ook in Jeruzalem moet het kwantitatieve hoogtepunt vlak voor de Tweede Wereldoorlog hebben gelegen, met meer dan 200 zusters en evenzoveel kostschoolmeisjes. Bij de bevrijding in oktober 1944 werden het kloostercomplex en de scholen volledig verwoest. Vanaf 1950 is alles herbouwd. Maar al in de jaren vijftig groeide de kritiek op het onderwijs door religieuzen, omdat zij niet bij de tijd zouden zijn (Van Heijst, Derks \& Monteiro 2010, 161-162). $\mathrm{Na} 1960$ raakten internaten zoals gezegd uit de mode. In 1965 woonden er 82 zusters ursulinen in Venray en telde het internaat nog 90 leerlingen.

In 1971 bracht Jos Kocken een rapport uit over de spanningen in het klooster Jeruzalem. Er leefden toen 65 zusters, van wie 47 boven de 65 jaar, met een conservatieve kern van hoogopgeleiden, terwijl de jongeren (zowel de hoog- als lageropgeleiden) wat progressiever dachten. Tussen de koorzusters die het onderwijs verzorgden en de hulpzusters uit de huishoudelijke ondersteuning bestond weinig communicatie. Deze leeftijdstegenstelling en verticale gezagsverhouding leidden voortdurend tot conflicten en crisis. Kocken deed dan ook de aanbeveling om de communiteit op te splitsen (Kocken 1971, 4-9). Inderdaad gingen groepjes zusters verspreid over Venray in gewone huizen wonen, zodat het immense klooster half leeg kwam te staan. In 1973 is het grootste deel van Jeruzalem verkocht aan de gemeente, waarna het de bestemming van gemeentehuis kreeg, die het nog steeds heeft (Bouwels 1979; Bak et al. 1998, 80-83). In 1980 is het internaat gesloten en bleven er nog een kleine dertig zusters over, verspreid over enige huizen. De scholen werden steeds meer door leken geleid. In 2005 woonden er nog zeven ursulinen in Venray, op een na allen in het moederhuis Sint Oda. In 2017 namen Poolse ursulinen het bestuur over het zestal resterende zusters over.

De volgende groep zusters kwam aan als vluchtelingen. In 1876 verbande de Duitse regering in het kader van de Kulturkampf katholieke kloosterlingen als staatsvijandige personen. Hierdoor kwamen toen in heel Limburg kloosters van Duitse religieuzen tot stand. De Zusters van de Goddelijke Voorzienigheid kregen van het gemeentebestuur van Venray toestemming om hier onderwijs te geven aan arme kinderen en om arme bejaarden te verzorgen. Vanaf 1880 werd hun Sint Jozefgesticht opgebouwd, met klooster, verzorgingshuis en scholen, onder andere voor "zwakbegaafde kinderen" (huize Sint Vincentius). Een kleine neventaak bestond in huishoudelijke ondersteuning in het internaat van de paters franciscanen, wellicht als tegenprestatie voor de levering 
van een rector. In 1969 woonden in het Sint Jozefgesticht nog 90 zusters, maar in de jaren daarna verhuisden de oudsten telkens naar andere kloosters. In 1990 waren er nog 15 zusters in Venray, in 2005 geen enkele meer (Asselbergs 1976, 16-22; Bak et al. 1998, 102).

In 1907 openden de Broeders van Liefde in Venray het Rooms-Katholiek Krankzinnigengesticht voor mannen Sint Servatius. De provincie Limburg had de broeders, wier moederhuis in het Belgische Gent lag, uitgenodigd. Onmiddellijk stroomde de voorziening vol met 375 patiënten. De broeders verwierven spoedig een goede naam als een ultramoderne instelling met uitstekende medische en sociale zorg voor de verschillende categorieën patiënten. De broeders zelf hadden een hecht kloosterleven, maar velen van hen woonden verspreid in de paviljoens van Servatius om dag en nacht beschikbaar te zijn (Van Els 2005, 285; Bak et al. 1998, 120). Al snel namen zij (mannelijke) lekenverpleegkundigen in dienst, onder wie zij ook wierven voor hun eigen aanwas. Tijdens de oorlog raakte de instelling overbevolkt met bijna 5000 bewoners en bij de bevrijding liep ze zware schade op (De Jong 2006, 13).

Het aantal reguliere patiënten nam geleidelijk toe, met een top van 1071 in 1958, daarna liep het terug vanwege de invoering van nieuwe behandelwijzen. Een bijzondere categorie patiënten in de jaren vijftig waren priesters met psychische en vooral met seksuele problemen, religiosi aberrantes genoemd (Deetman et al. 2011, deel 1, 56 en 121-123). In 1965 woonden er op het terrein van de instelling $\sigma_{1}$ broeders. Zij leefden in de verwachting dat er nog jongeren bij zouden komen, want er werden plannen ontworpen voor uitbreiding van het klooster. Vier jaar later was de stemming omgeslagen, omdat niet alleen de jongeren het af lieten weten, maar ook verschillende broeders uittraden, onder wie hun directeur-overste. In plaats van de voorgenomen uitbreiding van het klooster besloten de broeders in 1968 om twee woningen in de wijk Veltum te kopen voor "broeders-nieuwe-stijl" (Van Els 2005, 285-287). Een belangrijk aspect van de nieuwe stijl was een betere scheiding van leven en werk. In dat jaar verbleven nog 44 broeders op Servatius, van wie 12 "rustende" (Buijs et al. 1998, 121). Daarna vertrokken gepensioneerde broeders meestal naar hun kloosters elders in het land, bijvoorbeeld het moederhuis in Eindhoven. In 1990 ging de laatste broeder met pensioen en een jaar later is de bestuurszetel opgegeven. Inmiddels zijn alle broeders weg uit Venray.

In het naburige dorp Oostrum (gemeente Venray) was een opleidingsklooster van de broeders, Sint Paschalis, waar in 1969 nog negen broeders verbleven. Maar de opleiding was een jaar eerder al overgebracht naar Tilburg, en Paschalis was ingericht als dependance voor patiënten van Servatius (De Jong 2006, 15-16). 
In 1908 begonnen de eveneens uit Gent afkomstige Zusters van Liefde van Jezus en Maria met het "vrouwengesticht" Sint Anna, voor wat wij nu psychiatrische behandeling noemen. Ook hier vond een gestage groei van aantallen zusters en patiënten plaats, waarbij al snel lekenverpleegkundigen in dienst kwamen. De zusters wedijverden met de broeders om de faam van de beste instelling van het hele land. Sint Anna stond in de jaren van 1930 tot 1950 bekend om de warme zorgsfeer. Maar deze eiste een zware tol van de zusters, omdat zij de professionele verpleging moesten combineren met een streng kloosterleven (Van Heijst, Derks \& Monteiro 2010, 367-369). De verstandhouding tussen zusters en verpleegkundigen leek op een hecht gezin, met veel aandacht voor ontspanning. Hier hadden de zusters wel belang bij, want zij wierven - zonder veel aandrang - onder de verpleegsters (Billekens \& De Boeck 2005, 384, 387). Omdat Sint Anna moederhuis was en tijdens de oorlog aanvankelijk relatief veilig lag, zijn er veel patiënten van elders ondergebracht, tot in totaal 1700 . Bij de bevrijding zijn ook hier de meeste gebouwen verwoest.

Vanaf ongeveer 1960 nam het aantal zusters van Sint Anna af. In 1965 woonden er nog 60 in het klooster, in 1990 verliet de laatste de actieve dienst. Een jaar later verhuisden bijna alle bejaarde zusters naar hun klooster in Eindhoven. Vier zusters bleven in Venray wonen, van wie er in 2005 nog drie over waren; tien jaar later was er geen enkele meer. In 1970 waren de twee psychiatrische instellingen al in één stichting ondergebracht, vanaf 1976 het Vincent van Gogh Instituut geheten, dat inmiddels is opgegaan in GGZ Noorden Midden-Limburg. In 1991 gaven de zusters hun bestuurszetel op (De Jong, 2006, 16 en 24; Bak et al. 1998, 135-139).

In 1934 stichtten de Zusters Franciscanessen van de Stichting Charitas uit Roosendaal in Venray een ziekenhuis waarvan zij de gehele exploitatie voor hun rekening namen. Aanvankelijk viel de bezetting van de beschikbare bedden tegen, maar na de oorlog ontstond er juist gebrek aan bedden en aan zusters (Bakker \& Van Overbeeke 2014, 83, 186, 188). Bij deze congregatie daalde het totale aantal leden al sinds 1935 en was er al vroeg sprake van uittredingen, met als belangrijkste redenen een gebrekkige selectie (nieuwelingen werden te gemakkelijk aangenomen) en het zware kloosterleven (onder meer vanwege geregelde overplaatsingen en eenzaamheid) (ibidem 34, 211-213). De zusters moesten in het ziekenhuis op grote schaal beroep doen op lekenverpleegsters. Bovendien schoot hun financieel beheer tekort, waardoor er in de jaren vijftig te weinig geld voor het ziekenhuis beschikbaar was. Een bron van inkomsten waren de gediplomeerde zusters, voor wie een hogere vergoeding binnenkwam dan voor de ongediplomeerde, zodat het behalen van diploma's 
gestimuleerd werd (ibidem 188, 222). In 1965 waren er nog 27 zusters in het kort tevoren geheel vernieuwde ziekenhuis werkzaam. Een jaar later droegen zij het bestuur over aan een burgerlijke stichting. In die tijd gingen veel zusters van deze congregatie hun werkzaamheden verleggen naar assistentie in parochies. In 1988 vertrokken de laatste tien, bejaarde, zusters uit Venray (Bak et al. 1998, 155-157; Bakker \& Van Overbeeke 2014, 277).

Twee jaar na de Tweede Wereldoorlog vestigde de orde der Ongeschoeide Karmelieten zich in het dorp Smakt, gemeente Venray. Zij bouwden bij de bedevaartskapel van Sint Jozef een klooster waarin hun filosofie- en theologieopleiding werd ondergebracht. In 1965 verbleven hier nog ongeveer 40 paters, fraters en broeders. Maar net als bij de franciscanen werd de opleiding in 1967 verplaatst, in dit geval naar Amsterdam. Zodoende telde het klooster van Smakt twee jaar later nog 14 karmelieten (Bak et al. 1998, 165-169). In 2005 was er nog één pater actief als pastoor van Smakt en drie aangrenzende parochies. Niet veel later is ook hij vertrokken.

In de jaren tussen 1962 en 1968 lieten de missionarissen van Marianhill een ruim kleinseminarie in Venray bouwen. Maar er kwamen nauwelijks studenten. Meer dan tien paters en broeders hebben er in deze jaren niet gewoond. Kort daarna is het complex verkocht (Bak et al. 1998, 171-172).

De befaamde Piusalmanak, jaarboek van Katholiek Nederland van jaargang 1965 toont geen aanwezigheid van andere religieuzen in Venray. De betrokken acht ordes en congregaties hadden in dat jaar in Nederland samen 3143 leden, van wie volgens bovenstaande telling 13,7\% in Venray woonde.

\section{Externe sociale verhoudingen}

In Venray zelf weten de meeste inwoners nu weinig meer van de kloosterlingen en kijken de ouderen die dat nog wel doen meestal met enige sympathie terug op hun bemoeienissen. De gemeente Venray had in 1965 in totaal 24.067 inwoners, van wie ongeveer twee derde in de kom woonde en het andere derde was verdeeld over tien dorpen. In 2005 waren er in totaal 39.044 inwoners, nu voor drie kwart in de kom gevestigd en een kwart in de (nauwelijks gegroeide) dorpen (Gommans-Loonen 2006, 5-9). In 1965 was het overgrote deel van die inwoners katholiek en stonden plaatselijke politici tamelijk positief tegenover kerk en kloosters. Deze kloosters betekenden veel voor de naam en werkgelegenheid van Venray. Verder dreef de Venrayse economie tot na de Tweede Wereldoorlog op landbouw en veeteelt. De oorlog leidde, zoals eerder vermeld, tot enorme verwoestingen in het centrum en in enkele dorpen. Maar de wederopbouw bracht ook een industrialisatie op gang die nog steeds voortgaat (Gemeentegids Venray 2005/2006, 15). 
In de inleiding is al opgemerkt dat het aantal kloosterlingen in Venray absoluut en zeker in verhouding tot de overige bevolking vlak voor en tijdens de Tweede Wereldoorlog nog beduidend groter was dan in 1965. Maar in de oorlog was er sprake van een noodsituatie, door de gedwongen huisvesting van vele elders verjaagde personen. Met andere woorden, het relatief hoge aantal kloosterlingen ten opzichte van de gehele bevolking van Venray kort voor de oorlog week niet erg af van de landelijke cijfers, ofschoon de Venrayse aantallen wel in de richting gingen van een religieuze concentratie of kernplaats.

Aan het begin van onze onderzoeksperiode, in 1965, telde Venray alles bij elkaar 431 religieuzen. Een dertigtal van hen woonde in de omringende dorpen die bij de gemeente behoren. Dit waren nog niet eens alle katholieke geestelijken, want binnen de gehele gemeente waren er ook nog eens ongeveer 25 seculieren werkzaam, priesters van het bisdom Roermond die de verschillende parochiekerken bedienden. In hetzelfde peiljaar had de kom van Venray 12.184 inwoners, plus 3053 patiënten in de instellingen, en 8830 inwoners van de tien 'kerkdorpen' (Gemeente Venray, afdeling bevolking, overzicht 1965). Op dit totaal vormden de kloosterlingen 1,66\% van de bevolking, maar van de inwoners van de kom was dit 3,3\%. Ook in de jaren zestig waren de paters, broeders en zusters nog veel voorkomende en goed herkenbare personen in het straatbeeld. Zij bekleedden zelfs sleutelposities in het onderwijs en het gemeenschapsleven.

We zagen dat er in Venray vanaf 1965 geen kloosterlingen meer bijkwamen, maar dat er alleen overleden of vertrokken. In 1975 waren er bij benadering nog 280, in 1985 160, in 199550 (Bak et al. 1998; Bouwels 1979; De Jong 2006). In 2005 waren er nog 14 religieuzen over, terwijl de bevolking van de kom van Venray meer dan verdubbeld is ten opzichte van 1965. Het aantal patiënten van de instellingen is gezakt tot 650 .

$\mathrm{Bij}$ het palet aan kloosters behoorde een bepaalde sociale taakverdeling. Want in het algemeen waren de kloosterlingen elkaars concurrenten, zeker bij de werving. De scholen en speciaal de internaten in Venray waren immers impliciet bedoeld voor de opleiding van nieuwe religieuzen. Ruw ingedeeld richtten de franciscanen en ursulinen zich voornamelijk op de hogere standen, de rijken en de gegoede middenstand, in geheel Nederland, de zusters ook nog op het Duitse grensgebied (vgl. Baan 1965, 227). Hun internaten concurreerden met andere gerenommeerde katholieke kostscholen. De broeders en zusters van Liefde benaderden de lagere middenstand en de arbeiders uit de verre omgeving. De zusters van de Goddelijke Voorzienigheid verzorgden de plaatselijke armen en wierven ook onder hen: arbeiders en behoeftigen. 
Alles bijeen waren de kloosters rond 1970 nog grote werkgevers in Venray. Bij de enigszins deftige internaten waren heel wat mensen in dienst. Bij de psychiatrische instellingen waren ook grote aantallen verpleegkundigen werkzaam, aanvankelijk meestal intern, zeker tijdens de opleiding. Werkten er rond 1960 in Servatius en Anna samen ongeveer 400 leken, in 1981 was de inmiddels gezamenlijke stichting de grootste werkgever van Venray met 1700 werknemers (Buijs et al. 2007, 128). Verder kon de bevolking gebruik maken van faciliteiten van de instellingen: bijvoorbeeld de voetbalvelden, gymzaal en bibliotheek van Servatius werden graag benut (ibidem, 128). Zodoende vormden de kloosters en hun instellingen in de plaatselijke samenleving aanvankelijk machtsblokken, in economisch, ideologisch en sociaal opzicht.

Uit dit overzicht kan de indruk ontstaan dat er in Venray maar één soort geloof werd beleden, de rooms-katholieke denominatie van het christendom. Maar er is vanouds een kleine protestantse minderheid, die nu verdeeld is over drie gemeenten: de Protestantse Gemeente (PKN), de Evangelische Baptistengemeente en de Molukse evangelische kerk. De Protestantse Gemeente heeft sinds begin jaren negentig haar thuisbasis in het Zonnelied, de kerk die de franciscanen ooit gesticht hadden. Verder zijn er sinds de jaren tachtig zowel een Turkse als een Marokkaanse moskee ingericht voor de islamitische geloofsgemeenschappen. Tot slot kan nog kort het gebied van de alternatieve spiritualiteit genoemd worden, waarbij deelnemers meestal een holistisch geloof aanhangen. In de loop van de jaren tachtig startten verschillende alternatieve genezers een praktijk in Venray. In de jaren negentig bood de Volksuniversiteit Venray cursussen aan zoals astrologie, tai chi en Bowen-therapie. Toen werd in Venray ook jaarlijks een meerdaagse paranormale beurs ingericht, die publiek uit de hele regio trok en die nog steeds georganiseerd wordt (Jespers 2007). Maar de alternatieve spiritualiteit lijkt sinds ongeveer 2010 over haar hoogtepunt heen te zijn.

\section{De Venrayse terugval in vergelijking met de Nederlandse}

Een vergelijking tussen de geschiedenis van de kloosterlingen in de periode van 1965 tot 2005 in Venray en in Nederland als geheel geeft meer inzicht in de mogelijke uniciteit van de casus. In chronologische volgorde komen overeenkomsten en verschillen aan de orde.

Als we teruggaan naar de onmiddellijke voorgeschiedenis van de terugloop, valt er al een verschil op. Zoals vermeld, moet het grootste aantal kloosterlingen in Venray kort voor de Tweede Wereldoorlog gelegen hebben. Maar 
op landelijk niveau is het grootste aantal juist gesignaleerd in 1967 . Het is niet aannemelijk dat de terugloop in Venray al twee decennia eerder was begonnen dan in de rest van het land. Maar dit is moeilijk vast te stellen, omdat de oorlog in Venray zoveel schade toebracht, ook aan de kloosters, dat hier zeker sprake was van een breuk in het religieuze leven.

In de jaren vijftig, tijdens de wederopbouw van Venray, rezen ook in de kloosters vragen over de zin van de strenge regels. De franciscanessen in het ziekenhuis kampten al met terugloop vanwege de zware combinatie van ziekenzorg en kloostertucht. In sommige kloosters zijn toen de zwaarste regels afgeschaft, zoals bij de franciscanen vermeld werd.

De snelle afname van religieuzen na het midden van de jaren zestig past in het algemene patroon van de modernisering. De kloosterlingen die nog werkzaam waren, moesten hun werk bij pensionering beëindigen, terwijl zij vroeger doorgegaan zouden zijn totdat ze niet meer konden. De ooit gerenommeerde internaten trokken nauwelijks leerlingen meer en de psychiatrische zorg vergde minder verpleegkundigen. In de betreffende scholen en instellingen namen gediplomeerde leken de taken van de kloosterlingen over, aanvankelijk alleen op de werkvloer maar ten slotte ook in het bestuur. Deze overgang hield in Venray gelijke tred met de landelijke ontwikkeling. Zodoende waren rond 1985 de kloosterlingen vrijwel verdwenen uit klaslokaal en ziekenzaal. Het vertrek van de overbodig geworden religieuzen verliep in Venray zoals op veel plaatsen in Nederland: de oversten trokken hun mensen terug naar kernplaatsen en sloten te klein geworden kloosters. Maar er ontstonden ook spanningen binnen de kloosters. De berichten van Baan en Kocken bevestigen dat er in de jaren zestig en zeventig grote tegenstellingen tussen de generaties ontstonden en dat gemeenschappen ontwricht raakten, speciaal die van de ursulinen en franciscanen.

Een belangrijke oorzaak van de spanningen in en rond het klooster was de verplichting van het celibaat. Dit was de hoofdreden voor de golf van uittredingen tussen eind jaren zestig en eind jaren zeventig. De Venrayse kloosters ontkwamen er niet aan, speciaal bij de broeders werd hier melding van gemaakt. Vervolgens roept dit onderwerp ook de vraag op of er naderhand situaties van seksueel misbruik zijn vastgesteld in de kloosters van Venray. Het tamelijk gedetailleerde rapport-Deetman noemt alleen een flink aantal gevallen bij de franciscanen, maar dit betreft voornamelijk de jaren voorafgaand aan de periode die wij onderzoeken.

In het hele land probeerden kloostergemeenschappen zich aan te passen aan de veranderende samenleving, waarbij we drie fasen onderscheidden. De eerste fase, namelijk het in kleine groepjes gaan wonen in woonwijken, was 
in Venray niet alleen een gevolg van idealisme (zich inzetten voor gewone mensen en in hun directe omgeving gaan wonen), maar ook een oplossing om een leefbaarder situatie in het klooster te creëren. Voor de broeders bracht het bovendien een scheiding van werk en eigen leven, het bevrijdde hen van de vroegere onbeperkte beschikbaarheid op het terrein van de instelling.

De tweede fase betrof een maatschappijkritische opstelling. Deze is in Venray vrijwel alleen te herkennen bij de franciscanen, vanaf 1984 met hun steun aan de nieuwe oecumenische basisgroep en in 2001 met de publicatie van het boek over Jezus als wijsheidsleraar. Sommigen van hen konden vanwege hun progressieve opvattingen ook in botsing komen met de conservatieve bisschop van Roermond, Gijsen. Religieuzen vallen niet rechtstreeks onder het gezag van een bisschop maar van hun overste, dus als een bisschop een kloosterling terecht wil wijzen, moet hij dat via de overste aanhangig maken. Maar als er in Venray ooit sprake was van zo'n conflict, dan is dat niet in de publiciteit gekomen. In het algemeen meed de bisschop fricties met religieuzen. Hij wist dat hun aantal snel terugliep, dus door rustig af te wachten losten eventuele problematische situaties met religieuzen zich dikwijls vanzelf op.

De derde fase, herbronning op de spiritualiteit van orde of congregatie, vinden we in Venray niet expliciet terug. Vervolgens is de mogelijkheid dat de kloosterlingen mede moesten wijken vanwege de opkomst van alternatieve religies en met name vanwege holistische spirituele praktijken vrijwel uit te sluiten. Deze laatste werden in Venray pas bescheiden merkbaar in de jaren tachtig, toen het aantal religieuzen al flink was teruggelopen.

\section{Omstandigheden en verklaringen}

Alles bij elkaar zijn er nog weinig argumenten opgedoken voor het snellere vertrek van de religieuzen uit Venray ten opzichte van de rest van het land. Daarom staan we nu wat uitvoeriger stil bij de eerder gestelde vraag of Venray een slecht leef- en werkgebied werd voor religieuzen, en zo ja, waarom dan. Vervolgens bekijken we andere verklaringen.

De bloei van de grootste Venrayse kloosters in de eeuw tussen 1850 en 1950 was te danken aan hun sociale dienstverlening: onderwijs in internaatsvorm en psychiatrische zorg. Toen in de tweede helft van de twintigste eeuw internaten uit de samenleving verdwenen en de taken van onderwijs en zorg onder overheidsregie kwamen en door gediplomeerde leken werden uitgevoerd, waren de actieve kloosterlingen overbodig. Op het eerste gezicht maakte de 
geografische ligging van Venray of de plaatselijke mentaliteit hierbij geen verschil voor het leef- en werkklimaat. Maar bij nader toezien lijkt de factor van de urbanisatie een rol te spelen. In de eeuw tussen 1850 en 1950 was Venray als plattelandsgemeente met spoorverbinding een veilige, gezonde buitenplaats voor internaten, theologieopleidingen en psychiatrische instellingen. Dit geografische isolement werkte toen dus als een tegenpool tegenover de gevaren van de grote stad. Na 1950 veranderden de sociale behoeften en daarmee de ideale locaties, waardoor Venray juist vanwege zijn geïsoleerde ligging uit de gratie raakte. Aan internaten voor kinderen van de elite was geen behoefte meer. Voor moderne theologieopleidingen genoten grote steden nu de voorkeur, want daar kregen aankomende priesters de kans om zowel kennis te maken met ernstige sociale problemen als op te trekken met jongeren van hun eigen leeftijd. De grote (landelijk opererende) psychiatrische zorginstellingen werden verkleind tot voornamelijk regionale centra.

De religieuzen die hierbij overbodig raakten, vertrokken meestal naar grote steden. Dit betreft personen wier levensvervulling is gelegen in belangeloze inzet voor medemensen. Toen hun oorspronkelijke werk (in onderwijs, ziekenzorg, psychiatrische verpleging) wegviel, zochten zij andere taken op het vlak van sociale of religieuze ondersteuning, zoals opvang van armen, daklozen of verslaafden, dan wel pastorale assistentie in parochies. Ook na hun pensioenleeftijd bleven zulke religieuzen zo lang mogelijk actief, sommigen tot op hoge leeftijd. Welnu, in Venray was aan dergelijke activiteiten maar in beperkte mate behoefte. De meeste overbodig geworden kloosterlingen die nog vitaal waren, moesten dus elders emplooi zoeken. Over het algemeen vonden zij in grote steden de sociale noodsituaties waarin zij iets konden betekenen. Ook hierbij speelt urbanisatie dus een zekere rol.

De bevolking van Venray juichte het vertrek van de religieuzen niet toe. Integendeel, dezen genoten nog lang krediet. De secularisatie zette hier, zoals in de meeste landelijke gebieden, wat later door dan in de grote steden van Nederland. De inwoners van Venray bleven dankbaar gebruik maken van de scholen, het bejaardenhuis en het ziekenhuis die door de religieuzen waren gesticht en tussen 1965 en 1990 allemaal in seculiere handen waren gekomen. De lokale en regionale dienstverlening van de scholen werd na een eeuw religieus bewind voortgezet door de burgerlijke overheid, zoals in de meeste katholieke plaatsen van Limburg en Nederland. Maar de vroegere cliënten van de internaten en psychiatrische instellingen waren niet uit Venray, maar uit de hele provincie en zelfs het hele land afkomstig. Juist zij lieten het afweten.

Een andere verklaring voor het snelle verdwijnen van de kloosterlingen luidt dat Venray net geen religieuze kernplaats is geworden. Er was wel een 
ongewone concentratie van kloosters, maar er staat slechts één moederhuis, dat van de ursulinen. Toch was ook Sint Anna jarenlang de hoofdvestiging van de betrokken congregatie. De zes andere ordes en congregaties die in Venray vertegenwoordigd waren, hadden elders hun basis. Maar het franciscanenklooster was lange tijd hun op één na belangrijkste van het land, omdat hier het filosoficum van hun priesteropleiding was gevestigd. Voor de relatief kleine orde van de ongeschoeide karmelieten was Smakt twee decennia lang, tot 1967 , vanwege hun priesteropleiding het belangrijkste klooster. De verplaatsing van beide opleidingen (van franciscanen en karmelieten) in 1967 heeft, zoals gezegd, met urbanisatie te maken, want professoren en studenten gingen respectievelijk naar Utrecht en Amsterdam. Maar de vijf eerder genoemde religieuze kernplaatsen zijn grote steden. Als provinciestad maakte Venray eigenlijk geen kans om zo'n kernplaats te worden.

Een laatste verklaring is het ontbreken van beschouwende ordes in Venray. Deze ordes hebben een intern doel, contemplatie, dat minder aan maatschappelijke ontwikkelingen onderhevig is. In plaatsen waar beschouwende ordes zijn gevestigd, verloopt de vermindering van het aantal kloosterlingen langzamer. Maar dergelijke kloosters zijn meestal in echte buitengebieden gevestigd. Daarvoor is Venray net weer een te grote plaats.

Het is niet zeker dat het snelle vertrek van de kloosterlingen uit Venray een voor Nederland unieke casus is. Om dit vast te stellen zijn vergelijkingen met talloze andere plaatsen nodig, waarvoor ons de gegevens ontbreken. Maar het staat vast dat het in Venray om grote aantallen personen ging, om een verhoudingsgewijs flink deel van de bevolking en om een snellere verdwijning van religieuzen dan gemiddeld in de rest van het land. Het is dus op zijn minst een opmerkelijke casus die heel wat sociale aspecten laat zien van het verdwijnen van het kloosterleven in Nederland, maar ook van de idealen en de enorme sociale inzet van talloze religieuzen. Helemaal belangeloos was hun inzet niet, want in termen van de rationele-keuzetheorie hoopten de meesten op een uiteindelijke geestelijke beloning in de vorm van een toegangsbewijs tot de hemel. Maar juist de beide compensaties die hier eeuwenlang voor hadden gefunctioneerd, namelijk maatschappelijk aanzien en carrièrekansen, waren razendsnel in rook opgegaan, wat zeker redenen waren voor het verdwijnen van het actieve kloosterleven in het algemeen.

Tot slot kunnen we ons afvragen of deze terugval voorkomen had kunnen worden. Hadden de kloosterlingen zich sterker moeten aanpassen aan de moderne samenleving, of hadden zij juist strakker aan de originele regels moeten vasthouden? In de theorieën troffen we twee tegengestelde verklaringen aan voor het dramatische verval. Gian Ackermans, Emke Bosgraaf en Peter 
Nissen menen dat de vernieuwingen in de kloostertucht onvoldoende en te laat waren. Maar Erik Sengers suggereert dat de verlichting van de tucht juist de indruk van verslapping wekte, waardoor het kloosterleven onaantrekkelijk werd. Als dit laatste klopt, zouden de strengste (beschouwende) ordes relatief de meeste aantrekking moeten vertonen. Welnu, in Venray kunnen we deze vergelijking niet maken, omdat er geen contemplatieven waren. Maar zoals gezegd, ontkomen deze in het algemeen evenmin aan de culturele druk als de actieve religieuzen. Annelies van Heijst, Marjet Derks en Marit Monteiro laten eigenlijk goed zien dat voor zover het de zusters aangaat de meningen en verwachtingen intern en extern uiterst verdeeld waren, zodat vernieuwingen weinig kans van slagen hadden. Voor velen, meest ouderen, veranderde alles te snel, maar voor jongeren en idealisten ging het niet ver genoeg (Van Heijst, Derks \& Monteiro 2010, 794, 883, 995). Deze auteurs maken eerder duidelijk dat een geseculariseerde welvaartssamenleving, gecombineerd met een vorm van verzorgingsstaat geen plaats meer biedt aan actieve religieuzen. In deze halve eeuw van culturele tegenwind zijn veel inmiddels flink afgeslankte religieuze congregaties er toch in geslaagd om aan de interne pluriformiteit ruimte te bieden binnen het kader van hun oorspronkelijke inspiratie (ibidem, 933).

\section{Conclusie}

De getallen van de afname van het aantal kloosterlingen in Venray wijzen op een terugloop tussen 1965 en 2005 die sneller verliep dan op de meeste andere plaatsen in Nederland. Voor wat met enige overdrijving een religieuze vrije val genoemd kan worden, zijn twee lokale oorzaken te noemen. De eerste is samengevat onder de noemer urbanisatie. In de tweede helft van de twintigste eeuw verloor Venray zijn voorkeurspositie als ideale buitenplaats voor internaten, theologieopleidingen en psychiatrische instellingen en verhuisden met name de theologen naar grote steden. Bovendien vertrokken de in het onderwijs en de zorg overbodig geworden kloosterlingen, voor zover ze nog vitaal en idealistisch waren, eveneens naar grote steden om nieuwe (sociale en pastorale) taken aan te pakken. De tweede oorzaak, die de keerzijde van de laatstgenoemde is, houdt in dat er in Venray zelf te weinig behoefte (of nood) bestond aan de nieuwe taken van de religieuzen; deze plaats bood hierbij hoogstens werk voor een paar kloosterlingen. Deze twee factoren worden weerspiegeld in het feit dat Venray tot 1965 voor vier van de acht betrokken ordes en congregaties ongeveer hun belangrijkste kloosters (van Nederland) 
herbergde en zodoende min of meer bij de religieuze kernsteden gerekend kon worden, waarna al deze centrale vestigingen op één na in rap tempo naar grote steden verplaatst werden. Venray als relatief geïsoleerde provincieplaats kon de resterende religieuzen niet vasthouden.

We kunnen moeilijk aantonen dat het ongewoon snelle vertrek van de kloosterlingen uit Venray een voor Nederland unieke casus is. Dit neemt niet weg dat Venray een hoogst opmerkelijke casus is van het verdwijnen van een veelkleurig religieus leven waarin een geweldige sociale inzet was betoond.

\section{Literatuur}

Ackermans, G. (1999),

Repertoires en strategieën van geestelijke leiding in De Kloosterling, vaktijdschrift voor leken en religieuzen (1929-1971), in: Monteiro, M., P. Nissen \& J. de Raat (red.), Steun en toeverlaat. Historische aspecten van geestelijke begeleiding, Hilversum: Verloren, 57-76.

Adriaansens, I. et al. (2004),

Pelgrimeren door de tijd. Jubileumuitgave bij het 20-jarig bestaan van de Venrayse Basisgroep 'Heel de Kerk, Heel de Wereld', Venray: HdKHdW.

Asselbergs, L. (1976),

Zusters van de Goddelijke Voorzienigheid 1876-1976, Steyl: Zusters van de Goddelijke Voorzienigheid.

Baan, MA. (1965),

De Nederlandse minderbroedersprovincie sinds 1853, Assen: Van Gorcum.

Bak, C.G.M. et al. (1998),

Twaalf stenen uit de stroom. De twaalf kloosters van Venray, Venray: Stichting Gedenkteken Kloosters.

Bakker, C.T. \& G. van Overbeeke (2014),

Zusters in de zorg. Een geschiedenis van Franciscanessen van Charitas, Zutphen: Walburg Pers.

Billekens, A.-J. \& L. de Boeck (2005),

Handen uit de mouwen, in: Billekens, A.-J. et al., 100 Jaar psychiatrie in Venray. Geschiedenis van de psychiatrische instellingen Sint Anna en Sint Servatius, Zutphen: Walburg Pers, 375-394.

Bosgraaf, E. (2009),

Gebroken wil, verstorven vlees. Een historisch-psychologische studie over versterving in het Nederlandse kloosterleven (1950-1970), Groningen: dissertatie uitgegeven in eigen beheer. 
Buijs, F., Haenen, T. \& P. Thoben (2007),

Ten dienste van de medemens. Nederland en de Broeders van Liefde, Eindhoven: Museum Kempenland/Broeders van Liefde.

Cijfers aantallen religieuzen (https://www.knr.nl/organisatie/pagina.asp?pagina_id=43, geraadpleegd 1 mei 2018).

Cijfers Rooms-Katholieke Kerk (www.ru.nl/kaski/onderzoek/cijfers-rooms, geraadpleegd 1 mei 2018).

Dam, G. van (2006),

Voor kerk en mensenwereld. De priesteropleiding van de minderbroeders-franciscanen in Nederland 1853-1967, Nijmegen: dissertatie uitgegeven in eigen beheer.

Deetman, W., N. Draijer, B. Kalbfleisch, H. Merckelbach, M. Monteiro \& G. de Vries, (2011),

Seksueel misbruik van minderjarigen in de rooms-katholieke kerk, uitgebreide versie, Amsterdam: Balans.

Els, T. van (2005),

Een impressie van het vroegere gestichtsleven op Sint Servatius, in: Billekens, A.-J. et al., 100 Jaar psychiatrie in Venray. Geschiedenis van de psychiatrische instellingen Sint Anna en Sint Servatius, Zutphen: Walburg Pers, 217-303.

Groot, K. de, J. Pieper \& W. Putman (red.) (2013),

Zelf zorgen voor je ziel. De actualiteit van christelijke spirituele centra, Almere: Parthenon. Jespers, F. (2007),

De paramarkt: New Age en volksgeloof, in: Religie \& Samenleving, 2 (2), 125-143.

Heijst, A. van, M. Derks \& M. Monteiro (2010),

Ex caritate. Kloosterleven, apostolaat en nieuwe spiritualiteit van actieve vrouwelijke religieuzen in Nederland in de $19^{e}$ en $20^{\text {ste }}$ eeuw, Hilversum: Verloren.

Jong, A.J.C. de (2006),

100 Jaar psychiatrie in Venray (1905-2005). Het leven en werken van de Zusters van Liefde en de Broeders van Liefde in St. Anna en St. Servatius, Venray: brochure in eigen beheer.

Kocken, J. (1971),

De Ursulinen van de Romeinse Unie. Monografie van de kommuniteit Jerusalem te Venray, 's-Gravenhage: KASKI (Rapport nr. 318b).

Kok, J.A. de (2007),

Acht eeuwen minderbroeders in Nederland, Hilversum: Verloren.

Meijer, F. (2001),

Lichtbeeld: Jehosjoea van Natsrat, Rotterdam: Ton van den Ende PDV.

Nissen, P. (1997),

Sterven voor de wereld als metafoor en paradigma, in: Derks, M., J. Eijt \& M. Monteiro, Sterven voor de wereld. Een religieus ideaal in meervoud, Hilversum: Verloren, 9-16. 
Oecumenische Basisgroep Venray (www.basisgroepvenray.nl,geraadpleegd 1 mei 2018).

Piusalmanak, jaarboek van Katholiek Nederland (1965), Amsterdam: De Tijd.

Schepens, T., L. Spruijt \& J. Kregting, (2002),

De Rooms-Katholieke Kerk in Nederland. Een statistisch trendrapport, Nijmegen: KASKI (Memorandum nr. 326).

Sengers, E. (2003),

"Al zijn wij katholiek, wij zijn Nederlanders". Opkomst en verval van de katholieke kerk in Nederland sinds 1795 vanuit rational choice perspectief, Delft: Eburon.

Vugt, J.P.A. van (2015),

Kloosters op schrift. Een bibliografie over orden en congregaties in Nederland in de negentiende en twintigste eeuw, vijfde editie, Nijmegen: Dienstencentrum Kloosterarchieven. 